This item was submitted to Loughborough's Research Repository by the author.

Items in Figshare are protected by copyright, with all rights reserved, unless otherwise indicated.

\title{
Conclusions: The rising importance of supporter activism in European football
}

PLEASE CITE THE PUBLISHED VERSION

https://doi.org/10.1007/978-3-319-48734-2_14

PUBLISHER

Palgrave Macmillan

VERSION

AM (Accepted Manuscript)

\section{PUBLISHER STATEMENT}

This chapter was accepted for publication in the book Football and Supporter Activism in Europe: Whose Game Is It? and the definitive published version is available at https://doi.org/10.1007/978-3-319-48734-2_14

LICENCE

CC BY-NC-ND 4.0

\section{REPOSITORY RECORD}

Zheng, Jinming, and Borja Garcia-Garcia. 2017. "Conclusions: The Rising Importance of Supporter Activism in European Football”. figshare. https://hdl.handle.net/2134/33513. 


\section{Conclusions: The rising importance of supporter activism in}

\section{European football}

Jinming Zheng, Hong Kong Baptist University (HK)

Borja García, Loughborough University (UK)

It has been pointed out repeatedly by academics and practioners over the last few years (see for example, Conn, 1997; Giulianotti, 2005; Hamil, 1999; Hamil, Michie, Oughton and Warby, 2000; Hudson, 2001) the danger of an increasingly 'remote' relationship between association football clubs in Europe and their fans or supporters as a consequence of the commercialisation, or the commodification of football. One of the first academics to fully articulate that transformation was probably Anthony King (2002), who suggested more than a decade ago that the commercialisation of club football was resulting in significant changes in the forms of fandom, including the emergence of the new consumer fans. King (2002: 209) argued that 'large capitalist interests are gaining increasing political, economic and affective hold over individuals who are becoming not primarily citizens of a nation state but consumers of a corporation'. In general, a pessimistic view regarding supporters' marginal and passive role has been prevalent over the past few years.

However, the activism of the numerous supporters' organisations around Europe, headed by Supporters Direct Europe and Football Supporters Europe has started to yield some credible results. This has attracted the attention of policy makers, football governance stakeholders and, as this book now clearly reflects, academics. This collective volume is the first attempt to bring together research from different parts or 
Europe on supporter activism, in order to understand the divergence and convergence of those dynamics, and the extent to which supporters are being heard by the political and football authories. Most research until now focused on single and small case studies, most of which has been focusing in Britain. The 12 cases on this book are clear evidence of an increasingly active and significant role of supporters in the management of clubs in many cases across a wide range of nations. Not only that. The chapters in this book also suggest to a variety of areas in which the supporters are having an impact. From the more usual role in club governance and/or ownership, to the fostering of inclusivity in the stands or even the commercial development of the club's televisionchannel. Supporters' simultaneous, and often organised efforts and collective actions to raise their voice and get involved in club affairs and even decision making, and to resist 'bad' decisions and over-commercialisation, are evident in both the traditional 'Big Five' leagues in England, Spain, Germany and Italy, and non-traditional regions including former Communist Bloc countries (such as Poland or the Czech Republic), and Turkey. This, to some extent demonstrates a trend of convergence in supporter engagement in football clubs in Europe. Also, there is evidence of the development of pluralistic characteristics in European club football, most evident in the participation of transgender spectators and their certain degree of satisfaction with club supporting and football watching. In addition, some clubs, for example Benfica, established its own TV to broadcast football matches, make a profit and communicate with football fans, which is a recent development in terms of football broadcasting.

There are several factors contributing to these developments. The most important factor is the development of commercialisation, commodification and marketisation of 
club football and the increasingly evident tension between these football clubs and their supporters. The tension between the political and economic interests of football on the one hand, and its cultural tradition and function on the other, results in many supporters', most notably 'die-hard' supporters' dissatisfaction and their concomitant unified actions to oppose 'modern football', to save their beloved football clubs out of mismanagement and financial quandary and to raise their voice and salience. Crisis of football clubs, most notably financial insolvency, provided supporters with golden opportunities to 'penetrate' their influence into club affairs and in some cases, get involved in decision making process. Supporters' voluntary fund-raising activities are the most pervasive form of supporter engagement in and contribution to their clubs, as evident in the cases mentioned in England, Italy, Czech Republic and Poland in this book. In addition, local identity is often a strong incentive for supporters' to get involved in club management and other affairs, as evident in Czech Republic, Italy and Poland.

\section{Football fans: Bigger profile, but still a marginal voice?}

However, despite these positive signs of development, supporters' role in club management and in particular the decision making process of clubs remains marginal. First, all of the aforementioned examples of supporters' active participation and engagement are confined to non-top clubs of non-top leagues. In other words, the role of supporters in club management and decision making remain significantly minimal in the clubs of first divisions of almost all nations studied and except for the German Bundesliga, or the Spanish cases of CA Osasuna, Atheletic Bilbao, Real Madrid and Barcelona FC, there is hardly evidence of supporters' ability to influence club decision making and management in other high profile clubs in Europe. Even the more 
'democratic' Spanish model does not represent a mainstream phenomenon as socio ownership and democratic president election is only evident in four Spanish clubs. Moreover, as the chapter on C.A. Osasuna has pointed out, the socio model is not without its problems and the real power of the socios could be really questioned.

Second, despite these positive developments of supporter engagement, there is a wide variation between clubs and nations. This is always bound to happen, given the hetereogeneity of supporter cultures across Europe. More importantly, despite the many examples of supporters' contribution, few of them have obtained actual power to participate in decision making and ownership. As reflected in the Italian cases detailed in this book, club owners tend to be reluctant to share ownership or include supporters in the decision making process despite their certain degree of reliance on supporters' financial donation to overcome dilemma. More inspiring examples can be found in Bohemians Prague 1905 in Czech Republic and Lechia Gdansk in Poland, though, where supporters successfully resisted club owners' decision and occupy a significant position in club's decision making and management. In brief, collective group actions including Supporters' trusts have been proven an effective way to integrate supporters' resource and strive for a greater say, as strongly advocated by Burnham (2000). It is evident from the cases of this book that it is better for supporters to work together collectively through good organisation and the proper use of professional skills, which echoes Crick's (2000) lesson learned from the experience of collective opposition to Murdoch.

However, supporters' decision making power remains small in comparison to other stakeholders most notably the club owners most often entrepreneurs and sponsors, broadcasters, the governing bodies and players in particular top players (Crowther, 2000; 
King, 2002; Malcolm, 2000) in 'the football figuration' (Clarke, 1992, quoted in Malcolm, 2000: 102). It is possible to argue that supporters' involvement in the governance of football clubs remains sporadic and fans remain 'the least powerful persons in the football figuration' (Dunning, 1999: 126, quoted in Malcolm, 2000: 102).

In order to obtain explanations, it is necessary to note the differences regarding supporter engagement between different national contexts. This, of course, makes holistic analysis extremely difficult. Yet, the chapters in this book allow us to identify meaningful dynamics. Supporters' involvement in the governance of football clubs including top clubs is both more traditional and significant in Germany and Spain (Brown and Walsh, 2000), while it is confined to clubs in the lower leagues in England and is very recent and limited in Italy. This is a very recent sphere of action for civil society activism, and as such is only developing. In addition, there are noteworthy differences regarding supporters' involvement between traditional Western European nations and nontraditional nations most notably former Communist countries. The former's limited degree of supporter participation is often related to the dominance of economic groups and commercialisation and commodification of association football, while for the latter where the degree of commercialisation is lower, the 'stifled' governance system often resonates with the Communist legacy of a centralised and less democratic but more bureaucratic system as well as corruption and less visible decision making processes. Yet, it is interesting to note that the end of Communism, the transition to market economy and the decline of state power in some clubs confer the opportunity on supporters to be engaged in clubs' decision making, as evidenced in the cases in Czech Republic and Poland. Last, even in the clubs where there is membership system which allows fan 
representation and participation in club affairs, the threshold for 'entry' is high and concomitantly supporters' participation is limited and conditional, which hardly threatens club owners' interests, as evident in some major clubs in Turkey,

The explanations of the limited, sporadic, conditional and often rhetorical supporter engagement lie in a) club owners' reluctance to devolve or share power with fans and their unwillingness to include supporters in the decision making in order to maximise and defend their own interests (in many cases, club owners' show no interest in sharing ownership, which is evidently illustrated by the Italian cases); and b) the question over the sustainability of supporters' interest in managing football clubs and the disincentives for their lasting commitment rather than temporary interest due to the high time and financial cost.

\section{One model does not necessarily fit all}

Perhaps one of the most innovative findings of this volume is a clear problematization of the widely accepted idea that football clubs owned by their members are necessarily more open, transparent and democratic that those adopting the form of a private limited company with shareholders. The different contributions in the volume seem to speak to one another in order to suggest that member clubs in Spain or even in Germany, which is normally acknowledge as the beacon of supporter activism see the impact of the fans in the decision-making of the club severily reduced when properly scrutinised. Whereas the structures might be prone to participation, the way in which they are implemented are not always as conductive to "supporter power" as we are led to believe. 
To further complicate the debate, the two contributions from Croatia suggest that, actually, in that country it is easier for supporters to bring a club's hierarchy to account under a private company model with shareholders than under the traditional membership club model.

This is highly relevant both to academics and policy-makers. In both cases, the contributions in this volume suggest that it is necessary to go beyond the theoretical structures of the different club ownership and supporter participation models in Europe. Research needs to dig deeper into the actual roles of stakeholders and the perceptions of both club management/owners and supporters of their respective roles. It is also very important, perhaps for policy-makers even more than for academics, to face these debates without prejudices. As this book demonstrates, the British supporters trust model is being exported to several European countries. The contributions of Osvaldo Croci on Italy and Dino Numerato on the Czech Republic are very illustrative to that extent. However, the authors also warn about the features of the model that seem not to work. Thus, it is necessary to recognise that structures are not good or bad, per se, in order to facilitate supporter engagement that brings the club hierarchy to account. As Sean Hamil has aptly argued recently, the reality is that "there is no substitute to good management" and that may come from an open membership structure or from a private limited company.

\section{Supporter activism beyond governance}

In addition to supporter involvement and participation, there are other problems that contemporary association football development in Europe needs to address. Giulianotti (1999) pointed out problems ranging from the longstanding hooligaism, racism and other forms of discrimination against minority groups (including LGBTQI such as transgender 
fans discussed in this book), to gender and class issues, many of which are discussed in detail in this book. Cases in this book provide some promising solutions to these problems. First, inter-regional and transnational cooperation is highly demanded to tackle hooliganism and discrimination. Not only are national football governing bodies and member clubs responsible for these issues but also cooperation at EU level is needed and the UEFA is expected to fulfil a role within the context of a growing European integration of football in conjunction with an increased transnational movement of hooligans. Second, as reflected in the Turkish context, a bottom-up approach which fully mobilises and harnesses the role of supporters should be adopted and may enhance the efficiency and effectiveness of anti-hooligan policies, in addition to the traditional topdown approach led by the government and governing bodies. Equally importantly, education and incentives and inducements should be used in addition to the often-used coercive policy instrument of sanctions and punishments. Third, it is evident from the Croatian case that the tension between supporters of 'rival' clubs can be effectively mitigated if these supporters face a common enemy - for example, corruption in the Croatian case. Similar cooperation between supporters representing 'rival' or different clubs can also be achieved in the case of the matches of the National Teams where they share the same national identity.

The future of the governance of association football clubs in Europe depends on the relative significance between the three aspects of football in general and club football in particular - its political salience and system, economic interests and cultural function and tradition. According to Millward (2011: 186), supporters' collective action to get involved in club affairs and their resistance to clubs' decisions are in many cases a 
demonstration of football supporters' desires to 'regain a sense of fans' cultural ownership of the club and the need to bring this back to the locality of the "space of places" rather than existing in the commercial and depersonalised "space of flows' where the club was for sale to whoever offered the most money'. Whether supporters will gain a more powerful position in the management of their clubs and decision making power, or even share the ownership, depend on whether and to what extent football can return to a culturally-embedded and supporter-centred game against the background of (1) the prevalence of commercial, market, commodified and mediatised elements permeating European club football in general and major leagues in particular and (2) the still evident centralised, bureaucratic and corruptive elements and even government intervention in the governance of football in many non-traditional and less democratic European nations. However, rather than seeing the marketisation, commercialisation, commondification and mediatisation of club football as negative, it is more constructive to see them as a doubleedged sword - which, on the one hand, marginalised the role and engagement of supporters, but on the other, opened the door for supporter contribution and involvement due to the financial crisis and insolvency of some football clubs as per the 'market rule'. Fans are more than merely passive consumers. They are active participants, the 'heart and soul' (Burnham, 2000: 45) property and 'lifeblood' (Brooking, 2000: 27) of football clubs.

\section{References}

Brooking, T. (2000).United for change.Soccer \& Society 1(3), 24-29.

Brown, A. and Walsh, A. (2000). Football supporters' relations with their clubs: A European perspective.Soccer \& Society 1(3), 88-101. 
Burnham, A. (2000). Time for change: Supporters direct. Soccer \& Society 1(3), 45-48.

Conn, D. (1997). The Football Business: Fair Game in the '90s? Edinburgh: Mainstream.

Crick, M. (2000). Shareholders united against Murdoch. Soccer \& Society 1(3), 64-69.

Crowther, P. (2000). Broadcasters vs. regulators: The threat to football from media company ownership of football clubs. Soccer \& Society 1(3), 30- 35.

Giulianotti, R. (1999). Football: A Sociology of the Global Game.

Giulianotti, R. (2005). Sport spectators and the social consequences of commodificationCritical perspectives from Scottish football. Journal of Sport \& Social Issues 29(4), 386-410.

Hamil, S. (1999).A whole new ball game? Why football needs a regulator. In S. Hamil, J. Michie, and C. Oughton (eds.) A game of two halves? The Business of Football. London: Routledge, pp. 23-39.

Hamil, S., Michie, J., Oughton, C. and Warby, S. (2000). Recent developments in football ownership. Soccer \& Society 1(3), 1-10.

Hudson, J. (2001). Critically examining the commercialisation of English football: A case for government intervention? Sociology of Sport Online 4(1). Available at: http://physed.otago.ac.nz/sosol/v4i1/v4i1hud.htm (accessed 25 March 2015).

King, A. (1998). The End of the Terraces: The Transformation of English Football in the 1990s (Revised ed.). London and New York, NY: Leicester University Press.

Malcolm, D. (2000). Football business and football communities in the twenty-first century. Soccer \& Society 1(3), 102-113. 
Millward, P. (2011). The Global Football League: Transnational Networks, Social Movements and Sport in the New Media Age. Basingstoke: Palgrave Macmillan. 